\title{
Naturalization and the Rights of Citizens
}

\section{Tāhā J. al 'Alwānī}

The subject of naturalization, which is an integral part of the concept of identity and its related problems, has been an issue in the Muslim world since its first contacts with western thought, culture, military, and politics. Even though the matter was decided, in practical terms, by the emergence of ethnic and geographic nation-states out of the wreckage of the Ottoman Empire, it remains an open topic at the cultural and academic levels. In fact, whether it is addressed as a challenge, an excuse, or as a means to an end, it remains a major and very sensitive question. As new ethnic and regional Muslim nation-states begin to show signs of instability, the subject grows more complex: it takes on new aspects of identity and affiliation and seeks to discover the best way of ordering relations between the peoples of each region or between them and the (factional, military, or otherwise) elitist governments controlling them.

With the stirrings of a new Islamic movement and its members' belief that Islam represents a viable political alternative, the question of naturalization has become a major challenge to them. In fact, it is often thrown in their faces by their secularist opponents. Thus the question has become instrumental in the current political struggle taking place in the Islamic world. Many Muslim governments cite indigenous non-Muslim minorities as an excuse to deprive their Muslim majorities, who often represent 98 percent of the total population, of the right to be ruled by the Shari 'ah. These are the same governments that discredit Islamic movements by viewing their very presence, principles, demands, and objectives as a threat to national unity. To counteract this "threat," then, they promulgate "emergency measures" and suspend constitutional legal codes.

Naturalization is the basis of nationalism, which gives identity to the modern state, and may be defined as an affiliation with a geographically defined region. Anyone who traces his/her lineage to that region is subject to all accompanying rights and responsibilities. Thus the bond between them is secular and worldly. The same is true of bonds between states, for they are entirely secular and measured in terms of profit and loss. It is essential that all citizens, regardless of their religious, ethnic or

Tāhā J. al 'Alwānī is a member of the Fiqh Academy of the Organization of the Islamic Conference, chairman of the Fiqh Council of North America, and president of the International Institute of Islamic Thought in Herndon, Virginia. This article was translated from the original Arabic by Yusuf DeLorenzo, IIIT Research. 
sectarian background, melt into this regional and profitable affiliation by casting off those parts of their background that might lead them into conflict with the state. In this sense, then, naturalization must take place in an atmosphere in which secular concepts, order, and methodology reign supreme. It was for this reason that secularists in the Muslim world saw the presence of non-Muslim minorities as a powerful argument that could be used to quell the demands of the Islamic political agenda. As a result, they opposed the Islamists and called for a "civil society," or what they suppose to be the opposite of a "religious society."

Several Islamist leaders have sought to deal with this issue by emphasizing that the Islamic agenda can create the desired "civil society," but within an Islamic framework. They have also asserted their readiness to accommodate many of the foundations of western society, as it is considered the best example of "civil society." Even so, many secularists remain unconvinced. For their part, Islamist leaders have given a great deal of thought to the secularists' objections to the Islamic agenda. Many have written on democracy, for example, and have proclaimed their acceptance of it and have found precedents for it in authentic Islamic sources. They have even announced their acceptance of the concepts of political pluralism, as one of the foundations upon which democracy is built, and of civil liberties, though some have done so with certain reservations. Rāshid al Ghannūshī, in his The Rights of Citizens, states clearly that Islam can accept naturalization, as it is popularly understood, and then proceeds to cite and explain the reasons for his claim and to give precedents for it. However, some secularist groups continue to reject and fear the Islamic political agenda. It seems that they prefer to live in the shadow of dictatorship and repression rather than accept the Islamic political agenda, regardless of how it may be altered.

We now come to a point of fundamental importance: understanding that the logic of Islamic thought (i.e., the basis of the Islamic agenda for civilization) is based on the constants, and not the variables, of Islam. Thus when the Islamic agenda for civilization looks at these variables, it does so from within the framework of those constants. In addition, borrowing concepts from a civilization with pagan roots and a significantly different system of principles differs considerably from borrowing a few simple words or translating mechanical, agricultural, industrial and other terminologies. Certainly, there are underlying ideas that must not be overlooked in terms of their effect on thought and culture. Still, there is less danger in borrowing terms from those fields mentioned above than there is in borrowing such terms based on underlying ideas and values that may have an affect on practical life-"nationalism" and "democracy." 
In what follows, some examples will be given of the dangers inherent in borrowing key concepts from entirely different civilizations. There is clearly a need to establish suitable regulations and standards for this type of borrowing so that the division between a society's variables and constants remains intact.

First, the word "citizen" did not appear until after the French Revolution of 1789. Before that time, people were grouped in terms of religion, language, ethnic, or tribal background. Nowhere did people affiliate themselves with the earth on which they lived. Second, secularism sought to minimize or overcome all differences between people, as differences cause problems for secularism and detract from its ability to establish comprehensive organizations based on expediency, pleasure, and worldly benefits, all of which it venerates in place of religious and moral values.

Third, the relevant texts of the Qur'an and the Sunnah, as well as the actual implementation of these concepts (i.e., the Pact of Madinah and the resulting decisions of the first caliphs and the Companions), indicate clearly that Islam is especially concerned with helping those who have not yet decided to convert to Islam to preserve their special religious, cultural, and ethnic characteristics.

A Muslim is guaranteed five basic necessities. Upon entering into a dhimmah contract, a non-Muslim is guaranteed these same rights as well as the recognition, defense, and protection of his/her particular communal or racial traits. If these are threatened, Muslim soldiers are duty-bound to defend them. Thus non-Muslims enjoy freedom of thought and comparison so that they may decide for themselves whether to adhere to their old ways or to convert. In fact, Islam views non-Muslims from the perspective of a universal message that rejects compulsion: "Let there be no compulsion in religion (Qur'an 2:256).

Islamic law protects non-Muslims in two ways: a) it offers them the same protection and rights given to Muslims, and b) it protects their special cultural and ethnic characteristics by guaranteeing the armed protection enjoyed by Muslims. It would seem, then, that non-Muslims enjoy a privilege not enjoyed by Muslims. How is it that a privilege may be viewed as a sign of contempt on the part of those who granted it? Islam grants respect and privilege to non-Muslim dhimmi subjects because it is a universal religion that views each individual in exactly the same way: a descendant of Adam, who came from dust, with some special characteristics that distinguish him/her from others. This is why Islam attaches such importance to all relationships and particularly to ties binding followers of the Abrahamic religions-Judaism, Christianity, and Islam-and to the rest of humanity. Ultimately, this diversity is to be used as a means of mutual recognition and acquaintance among the children of Adam. 
Fourth, there is no reason why the scholars of Islam, and Muslim social scientists in particular, should not engage in ijtihad and thus participate in building an ideal Islamic society. Ijtihad in matters of legal significance and creativity is needed within the Islamic movement, in order to address issues of social significance, as well as within the process of laying the foundations for Islamic civilization. Its practitioners must be careful not to embrace unfounded ideas or drawing analogies between Islam and other religions, for ijtihad is a human undertaking and therefore subject to error. It is also essential to understand that earlier rulings cannot be nullified-new rulings are additions to existing fiqhi knowledge.

Fifth, among the most consistently misunderstood and misinterpreted of all rulings are those related to the dhimmis (i.e., protected people) ${ }^{1}$ and the division of the world into two warring camps: the där al harb and the där al Isläm. Many legal scholars in the past misinterpreted the verses related to protected people, especially the following one: "Fight against such of them as have been given the scripture until they pay the tribute [jizyah] readily, having been brought low" (Qur'an 9:29). They overlooked the simplest meaning: that once vanquished, the new subjects would abide by Islamic rule and pay the jizyah. Instead, classical jurists interpreted the phrase "having been brought low" to mean that the vanquished should be humiliated as they pay the jizyah. Undoubtedly, it was this outlook that has created so many doubts and questions as to how a Muslim majority today would treat a non-Muslim minority.

These rulings have generated a great deal of criticism from modern secularists. If their original sources were considered anew and in light of progress in the social sciences, however, they might well provide solutions to long-standing problems and offer the basis for a harmonious blend of divergent elements. These may then be transformed into sources of strength instead of tension (i.e., racial tension in the United States). Indeed, owing to gaps in American social thought, ethnic, religious, and racial conflict can never be entirely ruled out. ${ }^{2}$

${ }^{1}$ In Towards an Islamic Theory of International Relations, published by IIIT in 1993, "AbdulHamīd AbūSulaymān writes: "In classical jurisprudence, this term (al dhimmah) is defined as a sort of permanent agreement between Muslim political authorities and nonMuslim subjects which pro-vides protection for Muslims and peaceful internal relations with non-Muslim subjects. In return, the latter accepted Islamic rule and paid the jizyah as a substitution for being drafted into the army. Jurists were fully aware that, in turn, the Muslim state was obliged not only to tolerate with sincerity the non-Muslims' faith, religious practices, and laws, but also to provide them with protection for their lives and properties: "Their blood is as our blood and their possessions are as ours"' (p. 28).

${ }^{2}$ Refer to 'Abd al Wahhāb al Masīnī's al Firdaws al Arḍī and his series of articles on the recent racial violence in Los Angeles in "Hākadhā Tadī" al Ablām," al Musawwar (Cairo: 1993). Compare these with what Fahmī al Huwaydi has written on these events. 
The peace and outward sense of tranquility found in North America, for example, and the relative ease in relations between different ethnic, religious, and racial groups are only apparent. Such harmony seems to be based on the principle that an individual's freedom ends where the group's freedom begins and on the open acceptance of each person's individuality and special characteristics as part of their human rights. This concept of freedom, however, is erroneous. Likewise, this ideal of human rights leaves much to be desired. The balance found in American society and in those that have followed its example may best be described as a balance of tigers, ${ }^{3}$ for western thought and philosophy, based on the rejection and attempted destruction of the "other," are inherently dualistic, argumentative, and contentious. Balance, if ever it occurs, is only a temporary stalemate among opposing forces or interests of equal power. For example, Europeans overcame the weaker Native Americans and then decimated them and took their lands. Thereafter, Europeans discriminated against people of color, women, and all other minorities. So whenever they speak of balance, they do so in terms of temporary solutions imposed upon them by the force of transient interests. The corollary to this is that such solutions are always subject to deterioration and breakdown.

So if the breakup of the Soviet Union is explained by the inability of Marxism, which is based on class struggle, to overcome the individual's natural inclination for self-expression, the other western model carries many of the same seeds. The idea of freedom alone may be transformed into a paradigm for a temporary balance that may well collapse under pressure, making of freedom a negative means to be employed in the destruction of true balance between groups.

What brings Americans together is the shared perception that they are a diverse group of people from different countries who have come together under a social contract to which they have access as taxpayers. Thus, a citizen's proper characteristic is the regular and timely paying of taxes, while at the same time benefitting from the facilities that those taxes provide.

Marxism was essentially an attempt to treat maladies in western thought and civilization. But it failed. This does not mean, however, that the patient has been cured and restored to health. On the contrary, it is far more likely that the illness has become more serious, and that the need for treatment has become more acute.

Islam, however, with its community-based organization and codified placement of each individual within the framework of the group, ad-

\footnotetext{
${ }^{3}$ This phrase was first used by Ismā'̄̄l al Färūqī in his lecture "The West and Us."
} 
dresses the psychological and spiritual needs of those living within its borders. Thus, no majority has the right to suppress a minority or to erase a minority's special or distinguishing characteristics. By the same token, no minority has the right to establish its uniqueness by detracting from the majority's rights or destroying its distinguishing features. Thus the Islamic concept of social balance is based upon mutual recognition of all of a society's traits and characteristics and upon their codification in a way that allows both the majority and the minority to develop and prosper. This allows a society's differing traits and characteristics to be transformed into a positive social diversity.

If understood in a conceptual context, Islam's treatment of nonMuslim subjects contains much that may prove to be of value in treating the hidden crises of modern societies, especially of those societies based on the American pattern. Historically, minorities in the Muslim world were able to maintain their cultures and ways of life because the Islamic system legislated and codified their special characteristics and thus accorded them state protection. In this way, non-Muslim minorities coexisted with Muslims for centuries and even played important roles in the Muslim societies in which they lived. In the Islamic world, there is hardly a city without its Christian or Jewish quarter. In the West, however, despite repeated waves of immigrants, all of their religious and other distinctions seem to have been lost in the melting pot of worldly secularism, which strips everything of its sacred nature.

Colonialism brought about attacks on all indigenous thought, both Muslim and non-Muslim. Gradually, the colonialists were able to give their own interpretations to many concepts, thereby confusing and misleading people on matters of religion. As a result, Islamic legislation for minorities came to be understood as degrading and segregationist, and certain minorities sought to destroy the system in the belief that only the majority would be affected adversely. However, both groups were harmed, for all religious and cultural distinctions fell victim to the foreign secularist agenda. Members of majority and minority groups would do well to remember the past before trying to block Islamic legislation.

Presently, Muslims are suffering from serious rifts in their cultural and intellectual lives as a theoretical war rages around them. One side features various factions of secularists, modernists, and atheists, and the other side the fundamentalists and traditionalists. The ummah does not need any of these factions or their compromises to reach some imagined political equilibrium. What it needs is to discover its own unique self and to define the frame of reference from which all of its factions may derive their principles, legitimacy, and standards. While the various factions may agree on the need for freedom, democracy, renaisance, and nationalism, 
they cannot agree on a single interpretation or method of implementation. Look at how democracy was rejected in Tunisia and Algeria when national polls showed that the Islamists had won. Clearly, the reason in both cases was differences in standards. In the wake of those rejections came a strong secularist current that preferred military dictatorship to Islamic rule. Clearly, the ummah's need for agreement on a single standard and frame of reference, as well as the rectification of its thought and its intellectual, cultural, political, and social foundations, is far greater than its need for accomodation and compromise, as these fade away as quickly as the circumstances that caused them. ${ }^{4}$

We do not want to be forced by political pressures to accept a median solution involving concessions by the secularists or nationalists in exchange for a proportional concession from the Islamists. We are fully aware that this takes place within the framework of the secular-materialist western culture that has imposed itself on every other civilization. The new center of this culture, the United States, views acceptance of its culture and worldview as an essential condition for the success of what it calls the "New World Order."

Had Muslim intellectuals sought to understand such concepts as naturalization and democracy within a universal Islamic milieu, a central Islamic culture, or at least within a self-sufficient Islamic culture, they might have avoided many of these [negative] observations or found satisfactory answers. Under the present circumstances, however, caution is required. For the most part, secularist and atheist intellectuals in the Muslim world, and in the Arab world in particular, contribute nothing more than translations of western criticism of Islam. They have cleverly altered these works in order to direct them against the Qur'an, the Sunnah, and Islamic law in general. Thus they have nothing new to say. It also follows that Muslim thinkers and intellectuals would be wasting their time if they tried to refute these borrowed criticisms.

Secularists, when they see Islamists engaging in innovative and independent thought, are quick to adopt traditional orthodox positions and to hide behind the same texts as the orthodox. For example, one of them has said that "We know, naturally, that the absolute equality spoken of by the revolutionary Islamic groups is incorrect from the standpoint of Islamic law. The texts of the Qur'an and the Sunnah speak unambiguously about differences in rank."

When Shaykh Nadīm al Jisr published an article, in the Lebanese daily newspaper al Nahär, that sought to find a theoretical connection be- 
tween the modern theory of light and supernatural beings (i.e., angels and jinn), Șādiq Jalāl al 'Azm refuted him by writing a book entitled Naqd al Fikr al Dinin (A Critique of Religious Thought). He asserted that the Qur'anic texts could be interpreted only according to the rulings of the first generations of Muslim scholars. Moreover, he argued that the knowledge spoken of in the Qur'an and enjoined upon Muslims is knowledge of the Shari'ah and nothing more. In support of his argument, he cited the definition of knowledge given by al Ghazāi (d. $505 \mathrm{AH}$ ) in his Ihyä', 'Ulūm al Dìn.

To follow up on this sort of scholarship done by the secularists would require a separate study. What is clear, however, is that it is very unlikely that the secularists will pay serious attention to the arguments of the Islamists. But that, in itself, does not detract from the value or need of Islamist thought, especially when it is placed in context and used in a way that seeks to deliver the Muslim mind from the crisis with which it is presently beset. Ijtihad, in the sense of independent and innovative thinking, is what Islamists need.

And now for my final point. From the beginning of our contact with the West until only a few decades ago, the Muslim mind was often occupied with the idea of rapprochement-an attempted bridging of the gulf between Muslim thought and the ideas and civilization of the West. This idea's time has now passed, for its negative ideas clearly far outweigh the positive. It has proven to be a failure. This is also true of comparative thought and of considering issues in Islamic thought from the perspective of western thought. If the idea of rapprochement helped to weaken the Muslim character and rob Muslims of their intellectual and cultural heritge, then the idea of considering issues from a western perspective has coerced Muslims into modernization or forced them to seek refuge in the past-to "progress backwards." Obviously, the consequences in either case have been to further widen the gulf between Muslims and the modern age as well as between Muslims and their counterparts in the modern world. 